\title{
PRDM16 wt Allele
}

National Cancer Institute

\section{Source}

National Cancer Institute. PRDM16 wt Allele. NCI Thesaurus. Code C97737.

Human PRDM16 wild-type allele is located within 1p36.23-p33 and is approximately 369 $\mathrm{kb}$ in length. This allele, which encodes PR domain zinc finger protein 16, is involved in the modulation of both fat cell differentiation and gene transcription. A reciprocal translocation $t(1 ; 3)(p 36 ; q 21)$ of the gene and the RPN1 gene is associated with myelodysplastic syndrome and acute myeloid leukemia. 